\title{
Modeling User Acceptance and Attitudes towards Using e-Government Business Services in the Saudi Private Sectors
}

\author{
Omar Baakeel \\ College of Business and Public Management University of La Verne, California, USA
}

\begin{abstract}
Nowadays, the provided services by governments internationally are strongly perform for delivering services via the Internet, particularly as a means of boosting cost-efficiency and reducing time spent on direct interactions with citizens. In Saudi, e-Government services in the private sectors are generally limited by difficulties in finding information related to the business practices along with the lack of computers availability and Internet access for many segments of the general population. Therefore, this paper aims at examining the relevance of the Technology Acceptance Model (TAM) for e-Government websites in the Saudi private sectors through an exploratory research study. This paper investigated the user acceptance and attitude levels towards using e-Government as a business consulting in the Saudi private sectors. An online questionnaire was used for the data collection purposes among 102 users from different business sectors in Saudi.
\end{abstract}

Keywords E-Government, Online Business, TAM, Online Marketing

\section{Introduction}

Through e-Government, country leaders expect to foster administrative reforms by transforming government functions, streamlining procedures, and enhancing administrative transparency. This expectation helps to resolve two seemingly contradictory objectives for e-Government in the respective country. On the one hand, leaders in Saudi Arabia are striving to utilize the various services of e-Government to reform as an engine for developing the economic growth, and to further combine definite roles for the fundamental government that may relies on adopting certain strategies for managing and monitoring the development of e-Government as stated by[1]. Several researchers (such as[2-5]) argue that understanding what the leaders mean by "administrative reform" provides a key to resolving this seeming contradiction. They outlined some of the e-Government applications now being introduced 1) transforming government functions (This aspect --generally focus on transforming government functions and promoting government services that can be accessed through online services, which concerns on handling the main procedures and application lists on the Internet); 2) reengineering government process (This aspect focus on reengineering government processes by making the processes more

* Corresponding author:

obaakeel@yahoo.com (Omar Baakeel)

Published online at http://journal.sapub.org/economics

Copyright (C) 2012 Scientific \& Academic Publishing. All Rights Reserved transparent and the procedure of examination and approval more streamlined); and 3) enhancing government transparency has been a driving force behind many of e-Government applications at both the national and local levels (Such expectation may helps to figure out two seemingly contradictory objectives for e-Government)[1]. This reengineering of the public administration, in turn, is motivated by a desire to stimulate economic progress[6]. More specifically, IT applications in government are intended to concurrently aid economic development by supporting a more decentralized and transparent public administration and to provide the central government with tools to provide the information necessary to high level government monitoring and control.

The TAM was originally introduced and studied as a means of understanding how users adopt and use new technology by evaluating the factors that influenced the decision to accept a new technology[7]. TAM is based on the belief "that perceived ease of use and usefulness can predict attitudes toward technology"[8]. As for this study, acceptance to use e-Government services can be measured through perceiving the ease of use and usefulness of these services along with attitude as shown in Figure 1.

However, individual attitude to use a system has long been identified as a cause of intention that independently associates with the perceived ease of use and perceived usefulness. Furthermore, researchers such as[9] have classified the attitude into two constructs: attitude toward the object and attitude toward the behavior. The attitude towards the individual behavior is refers to the user evaluation of a 
specified behavior. This evaluation of a specified behavior leads to certain behavioral intention that further results in certain behavioral action. Adapting this general principle, attitude toward use in the TAM model is defined as the mediating affective response between usefulness and ease of use beliefs and intentions to use a target system. In other words, a prospective user's overall attitude toward using a given system is an antecedent to intentions to adopt (Davis, 1989). In user participation research, it is also believed that, prior to system development; users are likely to have vaguely formed beliefs and attitudes concerning the system to be developed[10].

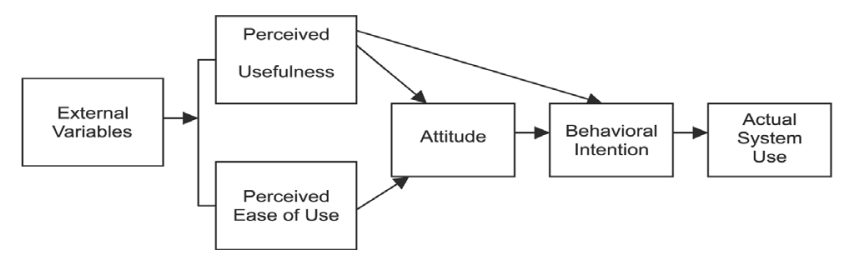

Figure 1. The adapted TAM to measure the user ease of use, usefulness, and attitude towards using e-Government

\section{Related Research}

Some scholars such as Lai and Pires in[11] have acknowledged the importance of measuring the individual believe to use actual system. They addressed the importance of e-Government on the potential to improve public administration efficiency by increasing convenience, performance and accessibility of government information and service to users. They highlighted the needs for reporting the e-Government potential to be grounded on in-depth understanding of target users' needs, perceptions and other factors influencing its uptake. Their study was mainly aimed on the identification and examination of the influencing factors of the e-Government portal satisfaction and adoption by individual citizens in Macao.

They constructed their model based on the integration of four success factors such as; information quality, system quality, perceived effectiveness and social influence. These factors were found to have a significant impact on the user satisfaction with the e-Government website, influencing intention to reuse. They also found that user perceptions about the e-Government portal influence user attitude towards the portal. The evaluation process was conducted based on Internet survey collected data from 464 online users of Macao's e-government portal. The result found that portal management needs to ensure ease-of-use, currency and accuracy of the supplied information. The content an e-government portal that is perceived by users to be easier to navigate is likely to facilitate satisfaction and reuse. Finally, the importance of social influence justifies, managerial actions aimed at improving e-Government portal acceptance by individual users and government employees.

Other researchers investigated the acceptance level of users to use e-Government services, example Alzahrani and Goodwin in[12]. They established their study based on the assumption extracted from different researches for the successful use of e- Government among citizens. Based on the Unified theory of acceptance and use of technology (UTAUT) model, they elaborated the man hypothetical framework that integrates the unique features of e-Government to improve the user acceptance and usage of e-Government in Saudi Arabia. The proposed model, based on UTAUT, includes the characteristics of e-Government, consideration and inclusion of trust, privacy, and Saudi culture and context.

\section{Method}

The quantitative method was used in this study to collect the data. The data were collected using an online survey. In addition, the evaluation method was established upon the use of a stratified cluster sampling frame based on the geographical direction in Saudi Arabia, including: north, south, west and east as a cluster. Among these clusters, we have assigned two e-Government services randomly. Therefore we selected 20 sectors among 70 ones in Jeddah city. 102 questionnaires were distributed between individuals who were working in these offices. The responses were collected and analyzed using SPSS.

\subsection{Research Instruments}

TAM is an information systems theory that models how users come to accept and use a technology. The model suggests that when users are presented with a new technology, a number of factors influence their decision about how and when they will use it, notably:

- Perceived usefulness (PU) - This was defined by Fred Davis as "the degree to which a person believes that using a particular system would enhance his or her job performance".

- Perceived ease-of-use (PEOU) - Davis defined this as "the degree to which a person believes that using a particular system would be free from effort" (Davis 1989).

- Attitude- Is the factor that cause of intention that independently associates with the use of actual system.

Table 1. Measurement of Variables

\begin{tabular}{|c|c|}
\hline Usefulness & \multirow{2}{*}{ TAM by Davis in[13] } \\
\cline { 1 - 1 } Ease of Use & \\
\hline Attitude & By Hung et al. in[14] \\
\hline
\end{tabular}

\section{Result}

Table 2 presents the homogeneity of variances for levels of processing which differed by program for the 102 participants.

Table 2. Homogeneity of Variances for Acceptance and Attitude

\begin{tabular}{ccccc}
\hline & Levene Statistic & df1 & df2 & Sig. \\
\hline Acceptance & 1.066 & 2 & 99 & .348 \\
Attitude & .057 & 2 & 99 & .945 \\
\hline
\end{tabular}


Table 3. Means, standard deviations and results of ANOVA tests for Ease of Use, Usefulness, and Attitude by age group

\begin{tabular}{|c|c|c|c|c|c|}
\hline & & $\mathrm{N}$ & Mean & Std. Deviation & Results of ANOVA \\
\hline \multirow{4}{*}{ Ease of use } & Age group 25-30 & 49 & 18.9592 & 2.66 & \multirow{4}{*}{$\begin{array}{c}\mathrm{F}(2,99)=.194 \\
\mathrm{p}=.824\end{array}$} \\
\hline & Age group 31-40 & 14 & 18.5000 & 2.53 & \\
\hline & Age group more than 40 & 39 & 18.6154 & 3.70 & \\
\hline & Total & 102 & 18.7647 & 3.06 & \\
\hline \multirow{4}{*}{ Usefulness } & Age group 25-30 & 49 & 18.5306 & 4.49 & \multirow{4}{*}{$\begin{array}{c}\mathrm{F}(2,99)=.858 \\
\mathrm{p}=.427\end{array}$} \\
\hline & Age group 31-40 & 14 & 17.3571 & 4.60 & \\
\hline & Age group more than 40 & 39 & 17.4103 & 4.12 & \\
\hline & Total & 102 & 17.9412 & 4.36 & \\
\hline \multirow{4}{*}{ Attitude } & Age group 25-30 & 49 & 19.4503 & 4.34 & \multirow{4}{*}{$\begin{array}{c}\mathrm{F}(2,99)=.954 \\
\mathrm{p}=.443\end{array}$} \\
\hline & Age group 31-40 & 14 & 18.3860 & 4.32 & \\
\hline & Age group more than 40 & 39 & 18.3302 & 4.56 & \\
\hline & Total & 102 & 18.8314 & 4.78 & \\
\hline
\end{tabular}

The total mean for ease of use was $18.76(3.75 / 5$ by the Likert scale) with $\mathrm{SD}=3.06$ indicating that the participants found the e-Government to be easy, as shown in Table 3. An analysis by age group reveals the mean for the age group 25-30 was 18.95 with $\mathrm{SD}=2.66$, while the mean for the age group 31-40 was 18.50 with $\mathrm{SD}=2.53$, and the mean for age group more than 40 was 18.61 with $\mathrm{SD}=3.70$. Results of the ANOVA test showed that $F(2,99)=.194$ at $p=.824$. As $p>.05$, there is no significant difference between the respondents with respect to the ease of use by the age group.

The total mean for usefulness was 17.94 (3.588/5 by the Likert scale) with $\mathrm{SD}=4.36$ indicating that the participants found e-Government to be useful, as shown in Table 3. An analysis by group reveals the mean for e-Government usefulness for the age group 25-30 was 18.53 with $\mathrm{SD}=4.49$, while the mean for the age group 31-40 was 17.35 with $\mathrm{SD}=$ 4.60 , and the mean for age group more than 40 was 4.12 with $\mathrm{SD}=.66$. Results of the ANOVA test showed that $\mathrm{F}(2,99)$ $=.858$ at $p=.427$. Again, as $p>.05$, there is no significant difference between the respondents with respect to the usefulness by age group.

In addition, the total mean for attitude was 18.8314 (4.38/5 by the Likert scale) with $\mathrm{SD}=4.78$ indicating that the participants attitude towards e-Government was high, as shown in Table 3. An analysis by group reveals the mean for e-Government attitude for the age group 25-30 was 19.4503 with $\mathrm{SD}=4.34$, while the mean for the age group 31-40 was 18.3860 with $\mathrm{SD}=4.32$, and the mean for age group more than 40 was 18.3302 with $\mathrm{SD}=4.56$. Results of the ANOVA test showed that $\mathrm{F}(2,99)=954$ at $\mathrm{p}=.443$. Again, as $\mathrm{p}>.05$, there is no significant difference between the respondents with respect to the attitude by age group. As $p>0.05$ for all tests, the results indicate that there are no significant differences between the respondents with respect to ease of use, usefulness, and attitude by age group.

\section{Conclusions}

This paper aimed at investigating the user acceptance levels and attitudes to use the e-Government business services in different private sectors located in Saudi Arabia. The study used TAM to formulate the relationship between the ease of use, usefulness, and attitude. The data collection was based on the mean of online survey distributed among 102 users. The data analysis was carried by measuring the mean and ANOVA for the collected data. The result showed that there are no significant differences between the respondents with respect to ease of use, usefulness, and attitude by age group.

\section{REFERENCES}

[1] L. Ma, et al., "E-government in China: Bringing economic development through administrative reform," Government Information Quarterly, vol. 22, pp. 20-37, 2005.

[2] K. Layne and J. Lee, "Developing fully functional E-government: A four stage model," Government Information Quarterly, vol. 18, pp. 122-136, 2001.

[3] D. M. West, "E - Government and the Transformation of Service Delivery and Citizen Attitudes," Public administration review, vol. 64, pp. 15-27, 2004.

[4] M. Warkentin, et al., "Encouraging citizen adoption of e-government by building trust," Electronic Markets, vol. 12, pp. 157-162, 2002.

[5] W. Wong and E. Welch, "Does E-Government Promote Accountability? A Comparative Analysis of Website Openness and Government Accountability," Governance, vol. 17, pp. 275-297, 2004.

[6] J. W. Seifert and J. Chung, "Using E-Government to Reinforce Government-Citizen Relationships," Social Science Computer Review, vol. 27, pp. 3-23, 2009.

[7] F. D. Davis, et al., "User acceptance of computer technology: a comparison of two theoretical models," Management science, pp. 982-1003, 1989.

[8] V. Venkatesh, et al., "User acceptance of information technology: Toward a unified view," MIS quarterly, pp. 425-478, 2003

[9] P. M. Bentler and G. Speckart, "Models of attitude-behavior 
relations," Psychological Review; Psychological Review, vol. 86, p. 452, 1979.

[10] H. Barki and J. Hartwick, "Measuring user participation, user involvement, and user attitude," MIS quarterly, pp. 59-82, 1994.

[11] C. S. K. Lai and G. Pires, "Testing of a model evaluating e-Government portal acceptance and satisfaction," Electronic Journal Information Systems Evaluation Volume, vol. 13, pp. 35-46, 2010.

[12] E. Alzahrani and D. Goodwin, "Towards a UTAUT-based Model for the Study of EGovernment Citizen Acceptance in
Saudi Arabia," World Academy of Science, Engineering and Technology, pp. 8-14, 2012.

[13] V. Venkatesh and F. D. Davis, "A theoretical extension of the technology acceptance model: Four longitudinal field studies," Management science, pp. 186-204, 2000.

[14] S. Y. Hung, et al., "Determinants of user acceptance of the e-Government services: The case of online tax filing and payment system," Government Information Quarterly, vol. 23, pp. 97-122, 2006. 